судженнями Ф. Фрьобеля, довільна гра дитини сприяє ії розвитку неповною мірою, тому завдання педагога - дисциплінувати інстинкти дитини через їі власні зусилля, спрямовані до досягнення корисної мети. Отже, в основу діяльності дитячого садка слід покласти ігризаняття. Серед основних предметів для ігор Ф. Фрьобель виокремлював: м'яч, кулю, валик, кубик, дощечки, палички, горох, папір, нитку, глину, пісок тощо. Зв'язок між цими предметами полягає у їх матеріальній основі, за їхньою допомогою можна вивчати форму, величину, вагу, число, колір, рух, тобто всі елементи людського знання. На цій основі Фрьобель увів для занять дітей новий дидактичний матеріал, назвавши його «дарами».

Основні ідеї Фрьобеля про врахування індивідуальних рис особистості, гуманне ставлення до дітей, демократичний характер виховного впливу, розвивальний характер виховання значною мірою збігаються з принципами, якими керуються сучасні теорія та практика дошкільного виховання: 3 принципами індивідуалізації, гуманізації, демократизації педагогічного процесу в дошкільних закладах. Німецький педагог визначив гру як засіб підвищення ефективності навчання, пізнавальної активності дітей, формування в них соціальних якостей. Фрьобелівська педагогічна система сприяла виокремленню дошкільної педагогіки в самостійну галузь науки $[1$, с. 6].

Перспективи подальших розвідок у цьому напрямку пов'язані 3 визначенням педагогічних умов упровадження ідей педагогічної системи Ф. Фрьобеля в дошкільну освіту України відповідно до умов сьогодення.

\title{
Література
}

1. Борисова 3. Фрідріх Фребель - засновник ідеї дитячого садка: (220 років від дня народження та 150 років від дня смерті) / 3. Борисова // Дошк. виховання. - 2002. - № 12. - С. 5-7. 2. Гершунский Б. С. Философия образования для XXI века. (В поисках практико-ориентированныХ образовательных концепций) / Б. С. Гершунский - М. : Совершенство, 1998. - 608 с. 3. Крутій К. Л. До 100-річного ювілею першого дитячого садочка на Запорізькій землі / К. Л. Крутій // Дошкільна освіта. - 2008. - № 3(21). - С.42-46. 4. Фребель Ф. Будем жить для своих детей / Ф.Фребель / сост., предисл. Л. М. Волобуева. - М. : ИД «Карапуз», 2001. - 288 с. 5. Фребель Ф. Воспитание человека / Мчедлидзе Н. Б. и др.. // История дошкольной и зарубежной педагогики. М.: Просвещение, 1974. - 464 с.

УДК 37(09)(477)

О. Г. Бутенко, кандидат пед. наук, доиент, Уманський державний педагогічний університет імені Павла Тичини

\section{ТЕХНОЛОГІЯ ГЕНДЕРНОГО ВИХОВАННЯ В. СУХОМЛИНСЬКОГО}

Бутенко О. Г. Технологія гендерного виховання В. Сухомлинського.

У статті здійснено аналіз творчої спадщини В. Сухомлинського, який розглядав виховання в підростаючого покоління якостей мужності і жіночності як одне 3 найважливіших завдань морального виховання особистості. Доведено, що універсальна педагогіка павлиського вчителя, яка поєднує в собі оригінальні ідеї та інноваційні технології, що звучать актуально і нині, є благодатним підгрунтям для гендерного виховання дошкільників.

Ключові слова: гендер, гендерне виховання.

Бутенко О. Г. Технология гендерного воспитания В. Сухомлинского.

В статье осуществлен анализ творческого наследия В. Сухомлинского, который рассматривал воспитание у подрастающего поколения качеств мужественности и женственности как одну из важнейших задач нравственного воспитания личности. Доказано, что универсальная педагогика павлышского учителя, которая сочетает в себе оригинальные идеи и инновационные технологии, звучат актуально и сегодня, являясь благодатной почвой для гендерного воспитания дошкольников.

Ключевые слова: гендер, гендерное воспитание. 
Butenko O. H. Technology education gender V. Sukhomlinsky.

The article analyzes the creative heritage of V. Sukhomlynsky that reviewed the education of the younger generation qualities of masculinity and femininity as one of the most important tasks of moral education of the individual. It is shown that universal education pavlyskoho teacher who combines original ideas and innovative technologies that sound important today, is fertile ground for gender Upbringing.

Key words: gender, gender education.

3 болем доводиться констатувати, що з кожним роком сучасну українську сім'ю, як соціальний інститут, все більше поглинає криза, що стала наслідком складної суспільнополітичної та економічної ситуації в країні. Усе важче знайти родину з позитивним психологічним мікрокліматом. Знервованість, роздратованість, грубість, сварки, відсутність милосердя у членів сім'ї стають звичними нормами життя. Соціальнополітична емансипація породила процес віддалення жінки від сім’і, знецінення іiі ролі берегині родини та сімейного щастя. Менш значущими для чоловіків стали їхні сімейні ролі, зокрема батьківство.

Наслідком виховання та умов життя, у яких перебуває сучасне молоде покоління, стає тенденція до вияву таких негативних явищ у поведінці і способі життя дівчини й юнака, як пияцтво, паління, наркоманія, підліткові сексуальні зв'язки, легковажна поведінка, ранні вагітності, високі показники венеричних захворювань та абортів серед молоді, випадки відмови від новонароджених дітей та ігнорування батьківських обов'язків. Свідченням цього $є$ перетворення жінки й чоловіка у бездуховні й аморальні істоти, не здатні виконати свою найважливішу місію - дати гідне нове життя.

Уважаємо, що витоками цих проблем є прорахунки статеворольової соціалізації, тобто, гендерного виховання молодого покоління.

Поняття «гендер» i «гендерне виховання» знайшли всебічне висвітлення у філософській і психолого-педагогічній думці минулого та сучасності. Різні аспекти проблеми статі, специфіки виховання дівчат достатньо грунтовно висвітлено відбито у працях педагогів та мислителів минулого (М. Бердясва, О. Бестужева, І. Бецького, I. Богдановича, Я. Коменського, Дж. Локка, А. Макаренка, Й. Песталоцці, Ж.-Ж. Руссо, К. Ушинського та ін.). Вивчення проблеми формування людини як представника певної статі мало місце і в роботах науковців початку XX ст. (М. Басов, П. Блонський, В. Бехтерев, А. Залкінд, С. Рубінштейн, М. Рум'янцев та ін.).

Питання статевої ідентифікації та диференціації останнім часом викликало інтерес у Г. Алексєєвої, О. Балакіревої, Т. Бендас, В. Бондаровської, Ю. Бурцевої, Т. Говорун, О. Кікінеджі, А. Кириліної, В. Кравець, В. Левицького, Л. Олійник, О. Петренко, Т. Поніманської, Н. Пушкарьової, А. Толстокорової та ін. Проблему підготовки молоді до виконання батьківських і материнських функцій, моральних аспектів підготовки школярів до сімейного життя порушують у своїх дослідженнях А. Антонова, Т. Гурко, З. Зайцева, В. Карпіков, О. Кононко, Д. Луцик, М. Машовець, Є. Насєдкіна, В. Постовий, Є. Сичова, Г. Чередниченко, С. Шуман та ін.

Благодатним підгрунтям для гендерного виховання дошкільників є цілісна педагогічна система, створена великим педагогом минулого століття В. Сухомлинським, який розглядав завдання виховання в підростаючого покоління якостей мужності і жіночності як одне 3 найважливіших завдань морального виховання особистості. Універсальна педагогіка павлиського вчителя, визначальною особливістю якої $\epsilon$ багатогранність, поліфонічність та всеосяжність, увібравши в себе найкращі надбання минулого та сучасного, поєднує в собі оригінальні ідеї та інноваційні технології, що звучать актуально і нині.

Mema cmammi - висвітлити гендерні аспекти виховання у творчій спадщині В. Сухомлинського.

В. Сухомлинський досконало вивчив психологію міжособистісних взаємин батьків і дітей, молодшого і старшого поколінь, гендерні аспекти виховання хлопчиків і дівчат. 
Учений-педагог глибоко розумів дитину, її переживання, почуття, прагнення і сподівання. Урахування психологічних особливостей хлопчиків і дівчаток В. Сухомлинський уважав одним із основних принципів педагогічної діяльності. А усвідомлення учнями, що i фізично, і морально вони є справжніми чоловіками і справжніми жінками, він називав найважливішою умовою формування громадянської, моральної та етичної зрілості вихованців.

Виховання якостей мужності i жіночності, на думку В. Сухомлинського, слід розпочинати вже в дитинстві. У хлопчиків необхідно затверджувати відповідальність та гідність чоловіка, виховувати розуміння, що вони - майбутні чоловіки і батьки, воїни, захисники Батьківщини. Важливими якостями, необхідними жінкам, він називав твердість, рішучість, жіночу гідність у відносинах із чоловіками. Виховання юнаків та дівчат В. Сухомлинський розглядав не як паралельні, а як взаємопов'язані i взаємозумовлені процеси. На його думку, діяльність колективу потрібно організувати так, щоб не було спеціальних чоловічих і жіночих видів діяльності, а відрізнялися лише місце і роль дівчаток і хлопчиків у здійсненні діяльності.

Серйозним засобом формування усвідомленого батьківства в педагогічній діяльності павлиського педагога стало утвердження Культу Матері в духовному житті дітей - культу, у якому «повага пройнята глибоким розумінням, і розуміння надихає повагу, пошану, любов, благоговіння, - вимагає від педагога мудро і піднесено говорити з дітьми про високу материнську місію» [3, с. 212].

Мистецтво виховання в сім'ї полягає в тому, що моральне багатство твориться взаємостосунками, де щільно переплітаються любов і добро з суворим обов'язком та працею, з особистим прикладом. В. Сухомлинський переконаний, що таким прикладом для дитини є перш за все Мати. Поруч з божественним культом Землі, Сонця, Неба та Води серед нашого народу живе віками культ Матері. Для педагога питання культури материнства, моралі сімейних відносин посідає чільне місце. Жінка завжди користувалася повагою в усіх народів. Ще з сивої давнині до нас дійшли пам'ятники і величні храми, збудовані на честь жінки-матері. Образ богині Великої Матері набув поширення ще тоді, коли людина вчилася виготовляти знаряддя праці з необробленого каменю. Українська етнопедагогіка порівнює матір з сонцем, теплом, добром, золотом.

Кожна дівчинка - майбутня жінка, майбутня мати. Потреба бути матір'ю закладена в самій жіночій природі. Однак, розглядаючи материнство як особистісну сферу жінки, В. Сухомлинський зазначав, що на вияв материнського ставлення вагомий вплив здійснюють чинні в суспільстві норми, традиції, цінності, ідеології та ідеали. Перший урок моральної готовності до материнства вихованці отримують ще в ранньому віці. «Усе залежить від виховання в дитинстві», - стверджував видатний педагог XX століття [3, c. 348]. Отож, дівчат потрібно постійно підводити до висновку, що материнство найвідповідальніша і найважливіша подія в житті жінки. Дівчинка має зрозуміти своє призначення: «Я, дівчинка, - завтрашня мати. Природою і суспільством на мене покладено високу місію - повторити в дітях себе і того, кого я люблю...» [2, т. 3, с. 355].

У своїх творах В. Сухомлинський розглядає найрізноманітніші гендерні проблеми сім’ї та особистості: яким має бути ставлення дітей до батька і матері, чоловіка до дружини. Особливу увагу він приділяе роботі 3 дівчатками. Саме підготовці дівчаток до усвідомленого материнства та великої місії матері В. Сухомлинський присвятив чимало своїх творів. 3 цією метою педагог уклав хрестоматію «Материнська краса», а також «Казки й бувальщини про Матір». Це оповідання й казки про велич, благородство, красу матері: «Мати 3 немовлям на руках, мати біля колиски - те саме, що прикордонник на своєму посту. Вона творить майбутнє, вона ж захищає його» [2, т. 2, с. 393].

За переконанням В. Сухомлинського, дівчинка повинна стати самобутньою і яскраво вираженою особистістю, а для цього необхідно виховати в дівчаток гордість, прагнути до їхнього духовного розвитку, життєвої активності. Великого педагога обурювало виховання, спрямоване на підготовку дівчаток до ролі домашньої господарки. 
В. Сухомлинський уважав, що «бути матір’ю, бути вихователем дітей - горда й почесна місія, але коли тільки цим обмежиться діяльність жінки - вона буде залежною істотою. Тільки яскрава життєва мета дає жінці духовну силу, яка робить іiі володарем i повелителем у сфері почуттів» [2, т. 1, с. 573].

Науковець підкреслював великий вплив суспільного виховання на формування гендерної поведінки, чоловічої і жіночої психології, статевої любові, продовження роду. «Виховання хорошої матері, хорошого батька, а значить, і хороших чоловіків і дружин це, по суті, одна 3 найважливіших цільових ліній роботи школи, адже матерями й батьками бути майже всім», - писав В. Сухомлинський [2, т. 1, с. 185].

Безперечно актуальними щодо реальних демографічних та психолого-педагогічних проблем, які стоять перед сучасним українським суспільством, є поради педагога щодо формування у підростаючого покоління усвідомленого батьківства. Основним агентом у цій нелегкій справі повинна стати школа. «Школа навчала готуватися до високої місії батьківства і материнства, до творення людини, до осягнення щастя і радощів буття. Морально підготувати завтрашніх батьків і матерів до сімейного життя, до людського кохання і дружби, до виховання дітей... - це означає виховувати мудрість батьків i матерів, які люблять одне одного, відданих одне одному чоловіка і жінку», - писав видатний педагог [3, с. 186].

В. Сухомлинський, засуджуючи безвідповідальне ставлення деяких батьків до виховання своїх дітей, зазначав, що досить часто молоді люди, будучи фізіологічно готовими до народження дітей, залишаються морально та психологічно незрілими для цієї ролі, не усвідомлюють своєї батьківської місії. Науковець підкреслював величезну відповідальність батьків і матерів перед суспільством за виховання своїх дітей. В. Сухомлинський радив так виховувати молодь, щоб у батьківстві і материнстві молода людина бачила вищий сенс свого буття. 3 цього приводу він писав: «С люди, які за рівнем свого морального розвитку не готові до шлюбу, i ïx одруження $\epsilon$ вищою мірою аморальним вчинком, злочином перед тим, чиє життя вони створюють» [2, т. 2, с. 396].

Виняткового значення у своїх численних працях В. Сухомлинський надавав формуванню в майбутніх батьків та матерів системи стійких етико-моральних цінностей, культури почуттів та взаємин, понять про усвідомлене батьківство та материнство. Він уважав, що статеве виховання є першоосновою емоційно-естетичного та громадянського становлення особистості, і спрямоване воно має бути на формування сім'янина.

В. Сухомлинський загострював увагу на потребі введення у зміст шкільної освіти матеріалів, спрямованих на виховання у молодого покоління духовного культу матері та батьківського авторитету, взаємоповаги між чоловіком і жінкою. Педагог неодноразово зауважував, що основою у вихованні майбутніх чоловіків i жінок повинні стати благородність стосунків у подружжі, мудрість у ставленні до дітей, особистий приклад батьківської мужності і материнської жіночності.

Задля виховання моральної готовності до материнства В. Сухомлинський радив використовувати етичні бесіди, присвячені високій місії матері: про любов, шлюб, народження та виховання дітей. Дівчатка мають усвідомити, що мати має вплив на всебічний розвиток дитини. На батьків покладалася особлива відповідальність за виховання дітей. Мати - природна вихователька своїх дітей, а батько - авторитет, захисник, годувальник. Однак результат виховання багато в чому залежить саме від особистості матері. Педагог дає настанови майбутнім матерям: «...Будьте мудрими й вимогливими в коханні. Кохання - палке почуття, але панувати над серцем повинен розум. Для дівчини це особливо важливо: природа й суспільство поклали на неї особливу відповідальність. Справжня жіночність - це поєднання ніжності і суворості, ласки й незламності. Без виховання в дівчат серйозного, мудрого погляду на кохання школа була б байдужою, казенною установою. Ми, педагоги, повинні особливо піклуватися про захист дівчат, про захист їхнього жіночого щастя, про виховання в них захисних сил, здатних протистояти брудові, вульгарності, мерзотності» [2, т. 1, с. 190]. 
В. Сухомлинський радив проводити Свято Матері і День дівчаток, щоб кожен хлопчик в такі дні вручив подарунок своїй матусі, сестрі чи бабусі, виготовлений своїми руками. Педагог також пропонував відвести у школі куточок для дівчаток, де б виставлялися книжки і брошури з анатомії, фізіології, гігієни дівчинки і жінки, про материнство; радив говорити з дітьми про велике і прекрасне - кохання, шлюб, батьківство, дітонародження.

Науковець із особливою шаною ставився до багатодітних сімей, наголошуючи, що сам устрій такої сім'ї готував дітей до майбутнього батьківства і материнства. Уже в ці роки дитина на підсвідомому рівні засвоювала прийоми виховання, граючись 3 лялькою, допомагаючи матері у вихованні молодших братиків і сестер, а ставши дорослою, використовувала педагогічний досвід у створенні власної сім’ї.

Аналіз творів В. Сухомлинського дозволяє говорити про слушність його поглядів щодо проблеми рівності статей, які, випередивши час, дають відповіді на актуальні питання, що стосуються розвитку і формування особистості школяра. Науковець особливу увагу звертає на гуманістичні настанови щодо статевого виховання молодого покоління, формування уявлень про батьківство та материнство, створення Культу Матері, подолання педагогами статевих стереотипів, що має вирішальне значення у формуванні гендерної культури сучасної молоді.

Отже, незважаючи на великий обсяг наукової літератури в руслі різних наук (історії, фізіології, медицини, біології, психології, соціології тощо), проблема підготовки дівчат до усвідомленого материнства та хлопців до усвідомленого батьківства залишається ще недостатньо вивченою і вимагає розроблення цілісного наукового підходу, спрямованого на створення теоретичної моделі зразкових матері та батька; визначення чинників розроблення науково-обгрунтованих методів формування усвідомленого материнства та батьківства.

Подальшого розвитку потребує розроблення оптимальних науково-обгрунтованих методів формування в дівчаток старшого дошкільного віку усвідомленого материнства.

\section{Література}

1. Кравець В. П. Гендерна педагогіка : [навч. посіб.] / В. П. Кравець. - Тернопіль : Джура, 2003. - 406 с. 2. Сухомлинский В. О. Вибрані твори [Текст] : в 5-ти т. / В. О. Сухомлинський. К. : Рад. школа, 1976-1977. 3. Сухомлинський В. О. Батьківська педагогіка / В. О. Сухомлинський. - К. : Рад. школа, 1978. - 264 с.

УДК 37.022:001.53

O. E. Жосан,

кандидат пед. наук, доцент,

Кіровоградський обласний інститут післядипломної педагогічної освіти імені Василя Сухомлинського

\section{ШКІЛЬНА НАВЧАЛЬНА ЛІТЕРАТУРА В ПЕРІОД ВІДБУДОВИ ТА ВДОСКОНАЛЕННЯ РАДЯНСЬКОЇ СИСТЕМИ ОСВІТИ (1944-50-ті рр.)}

Жосан О. Е. Шкільна навчальна література в період відбудови та удосконалення радянської моделі освіти в УРСР (1944-50-ті роки).

У статті аналізуються стан та тенденції розвитку шкільної навчальної літератури в Україні в 1944 - 1959 роках, з'ясовуються чинники впливу на формування ії змісту, визначаються структура та функції.

Ключові слова: зміст і структура загальної середньої освіти; зміст, структура, формат та функції шкільної навчальної літератури; принципи й методи навчання; науково-методичне забезпечення розвитку навчальної літератури.

Жосан А. Э. Школьная учебная литература в период восстановления и усовершенствования советской модели образования в СССР (1944-50-е годы) 